\title{
The natural product $\mathrm{NI}-07$ demonstrates effective anti-cancer properties against numerous cancer cell types
}

\author{
Lauren S. Gollahon ${ }^{1,}{ }^{2}$, Kyungwoo Lee ${ }^{1}$, Velvetlee Finckbone ${ }^{1}$, Yunseong J eong ${ }^{3}$ \\ 1. Department of Biological Sciences, Texas Tech University, Lubbock, Texas, U.S.A. 2. Texas Tech University Imaging \\ Center, Lubbock, Texas, U.S.A. 3. Division of Chemistry \& Molecular Engineering, Seoul National University, Seoul, \\ Republic of Korea.
}

Correspondence: Lauren Gollahon. Address: Department of Biological Sciences, Texas Tech University, Lubbock, Texas 79409-3131, U.S.A. Email: Lauren.gollahon@ttu.edu

Received: September 19, 2013

DOI : $10.5430 /$ jst.v3n5p30
Accepted: September 26, 2013

URL: http://dx.doi.org/10.5430/jst.v3n5p30

\section{Abstract}

Background: With the exception of a few anticancer agents, most chemotherapeutics currently used have varying effects on cancer cells and devastating effects on normal cells. Previously, we showed the natural product compound NI-07 was effective against breast cancer cells. Here, we investigated its effectiveness in vitro on six different cancer types. Additionally, NI-07 was tested in vivo by injecting human melanoma cells WM-266-4 into BALB/c mice and treating with NI-07, cisplatin or untreated.

Methods: For in vitro experiments, human cancer cell lines H1299, PC-3, AsPc-1, TT, Saos-2, and the rat C6 glioma cell line were analyzed in concurrently treated cultures of NI-07 $(36.6 \mathrm{mM})$, Taxol ${ }^{\mathrm{TM}}(2 \times 10-6 \mathrm{M}$ Taxol for $24 \mathrm{~h})$ or untreated for 1 week. In week 2, cells were analyzed for NI-07 effectiveness against resistance/recovery. Cell death was determined by cell counts, Trypan Blue exclusion and microscopy. Cell viability and cytotoxicity were measured by XTT. Three or more independent experiments were performed for each cell type. For in vivo experiments, 105 WM-266-4 melanoma cells were injected into the right flank of 5-week-old female nude mice (BALB/c nu/nu) and treated by gavage with $0.0035 \mathrm{mg} / \mathrm{g}$ NI-07. Untreated or Cisplatin $(0.0025 \mathrm{mg} / \mathrm{g})$ treated mice were used as control groups. Statistical significance was determined using One-way ANOVA, Tukey's HSD $(p \leq 0.05)$ and Cohens $\mathrm{d}(p \leq 2.0)$.

Results: In vitro results for NI-07 showed significant declines in cell viability between $48 \mathrm{~h}-4 \mathrm{~d}$ of treatment. Overall results demonstrated that the effect of NI-07 was comparable or superior to Taxol in killing cancer cells in all lines tested. Cancer cell recovery was less effective in NI-07 versus Taxol. In vivo results showed that NI-07 significantly slowed the tumor growth in comparison to untreated and cisplatin-treated mice.

Conclusions: NI-07, a novel natural product, effectively kills a wide variety of cancer cell types in vitro. Additionally, results showed that NI-07 was significantly more effective at slowing/reducing melanoma growth in a mouse model, in comparison to controls. Statistical significance $(p \leq 0.05)$ of NI-07 to Untreated, TaxolTM or cisplatin was determined using One-Way ANOVA and Tukey's HSD test.

\section{Key words}

NI-07, Natural product, Prostate cancer cells, Osteosarcoma cells, Pancreatic cancer cells 


\section{Background}

Current chemotherapies consist of drugs that disrupt mitosis (paclitaxel ${ }^{[1]}$ ), polymerize the cytoskeleton (vinblastine ${ }^{[2]}$ ), impede DNA-damage repair mechanisms (etoposide ${ }^{[3]}$ ), cause DNA cross-linking (cisplatin ${ }^{[4]}$ ), stop protein synthesis via DNA intercalation (doxorubicin ${ }^{[5]}$ ), inhibit RNA synthesis (actinomycin $\mathrm{D}^{[6]}$ ), and choke the blood and nutrient supply from the tumors (bevacizumab ${ }^{[3]}$ ). Taken together, it would seem unlikely that tumor cells should survive this onslaught of modern medicine. However for some cancers, prognoses are poor, remission is not guaranteed, recurrences develop and metastases arise ${ }^{[7]}$.

The major shortcoming of most current treatments is the inability to specifically target the cancer cells or cancer stem cells ${ }^{[7]}$, bypassing normal cells. Additionally, the majority of these drugs are not water-soluble and the nanotechnologies to deliver them are still in their infancy ${ }^{[8]}$. Therefore the main delivery vehicle (Cremophor ${ }^{\mathrm{TM}}$ ) adds compounding side effects ${ }^{[9]}$. Thus, normal cells and tissues are also exposed to these chemical insults, attenuating the clinician's ability to treat the disease immediately and definitively. The other major problem is that these anticancer agents can induce debilitating side effects that must also be treated, lest they prove fatal faster than the cancer ${ }^{[10,11]}$. The side effects from treatment can greatly reduce the quality of life for the patient. These side effects include rash and other skin changes, diarrhea, fatigue, hair loss, nausea and vomiting, decrease in blood cell counts, kidney damage and high blood pressure, to name the most common ${ }^{[12]}$. In many cases, patients are more afraid of these, than the cancer itself.

Although the majority of cancer treatments are not water-soluble, there are a few notable exceptions (e.g. imatinib ${ }^{[13]}$ ). Additionally, the technology is beginning to allow us to target cancer cells specifically (traztusumab ${ }^{[13]}$ ). Finally, molecular profiling is helping clinicians identify unique patient responses, allowing them to better tailor the treatment combinations ${ }^{[14]}$. However, it is clear that there is a critical need for effective anticancer agents that act specifically on the cancer cells without harming the normal cells or tissues of the patient. By developing such drugs, the goal is to make treatments more effective, recovery quicker and overall quality of life better because essentially, cancer cells die and normal cells are not affected.

In our previous study, the physical and chemical characteristics of the natural product compound NeoImmune ${ }^{\circledR}-07$ (NI-07) were described ${ }^{[15]}$. This $100 \%$ water-soluble compound is a mixture of several molecules implicated as having potential anticancer effects along with the novel reactive NI-07 species. In this study, we described its effectiveness in vitro in killing 5 out of 5 breast cancer cell lines while showing no cytotoxicity to normal human mammary epithelial cells and normal human mammary fibroblast cells. Here we expanded our investigations to determine the effectiveness of the natural product NI-07 on a variety of solid cancer cell types. These included in vitro testing on adenocarcinoma cells, sarcoma cells, glioma cells as well as investigating its effectiveness in vivo against melanoma. Our results indicate that NI-07 significantly treated all cancer cell types tested either comparably or more effectively than TaxolTM or cisplatin. Furthermore, its water solubility coupled with its lack of cytotoxicity makes NI-07 a strong candidate for development as a new anticancer drug.

\section{Methods}

\subsection{Cell lines and culture conditions}

All cell lines were purchased from American Type Cell Collection (ATCC) within the last 6 months and cultured under humid conditions at $37^{\circ} \mathrm{C}$ in $5 \% \mathrm{CO}_{2}$ following ATCC instructions. Tumor cells tested were as follows:

Pancreatic cancer, AsPc-1 ${ }^{[16]}$ (ATCC\#CRL-1682); non-small cell lung cancer, NCI-H1299 ${ }^{[17]}$ (ATCC\#CRL-5803); prostate cancer, PC-3 ${ }^{[18]}$ (ATCC\#CRL-1435); thyroid cancer, TT ${ }^{[19]}$ (ATCC\#CRL-1803); osteosarcoma, Saos-2 ${ }^{[20]}$ (ATCC\#HTB-85); melanoma, WM-266-4 ${ }^{[21]}$ (ATCC\# CRL-1676); rat glioma, C6 ${ }^{[22]}$ (ATCC\#CCL-107). The cells tested 
were chosen because they included four major solid cancer types: Carcinoma (pancreatic, lung, prostate), sarcoma (osteosarcoma), brain (glioma) and melanoma.

\subsection{Cell treatments}

NI-07 formulations of $1 \mathrm{X}$ were supplied by Yusahng LLC, dried by speed vacuum (Thermo, USA) and resuspended with sterile water to 100X. The molecular weight of NI-07 dihydrate is $191.19 \mathrm{~g} / \mathrm{mole}$. The liquid concentrate was added to the media formulations at the time of treatment to a final concentration of 20X. The 20X dosage equals a concentration of 36.6 $\mathrm{mM}$. Titration experiments (data not shown) determined this to be the approximate lowest lethal concentration to kill $\sim 50 \%$ of the cells (LC50) over the treatment period of 7 days. NI-07 test cells were continuously exposed for 7 days ${ }^{[23]}$. Medium alone (Taxol ${ }^{\mathrm{TM}}$ and Untreated) or Medium with NI-07 was refreshed on day 3. At $7 \mathrm{~d}$, treatment medium was replaced with fresh, untreated medium for the second week. Concurrently, Taxol ${ }^{\mathrm{TM}}$ at concentrations of $2.2 \mathrm{e}-7 \mathrm{M}$ were added for $24 \mathrm{~h}$ to parallel cultures of cells as previously described ${ }^{[24]}$ as a positive control for cytotoxicity and cell damage. Medium alone was used as the negative control. Cells were collected in tandem. Time points analyzed were $0 \mathrm{~h}, 24 \mathrm{~h}, 48 \mathrm{~h}$, $4 \mathrm{~d}$, and $7 \mathrm{~d}$ for both weeks. Week 1 was designated LC50 and week 2, Recovery. Results were obtained from three separate experiments consisting of three biological replicates per experiment unless indicated otherwise.

\subsection{Cell counts}

Cells were plated into 48-well CellBind ${ }^{\mathrm{TM}}$ plates (Corning, USA) at densities of 20,000 cells - 40,000 cells. Plating density was optimized based on cell cycle turnover rates. Twenty-four to $48 \mathrm{~h}$ after plating, cells were treated with NI-07 or Taxol $^{\text {TM }}$. Cells were harvested using Trypsin-EDTA (Invitrogen, USA) at the designated time points. Total cells for each well were counted using a ViCell (Beckman Coulter, USA), which also determines cell viability by Trypan Blue exclusion. Therefore, both cell numbers and percentage of viable cells within the wells was obtained. LC50 curves were generated in the first week. Recovery curves were generated by continued culturing of Taxol ${ }^{\mathrm{TM}}$ or NI-07-treated cells for a second week. At $7 \mathrm{~d}$ LC50 $=0 \mathrm{~h}$ Recovery. Thus at $0 \mathrm{~h}$ Recovery, medium was exchanged with untreated medium for the remainder of the experiment and refreshed again at $3 \mathrm{~d}$ Recovery. Cells were collected at $0 \mathrm{~h}, 24 \mathrm{~h}, 48 \mathrm{~h}, 4 \mathrm{~d}$ and $7 \mathrm{~d}$. Analysis of untreated controls was not done in Recovery due to over confluence and loss of viability by the end of week 1 .

\subsection{XTT cell viability assays}

The XTT assay is a widely accepted analysis technique for viability / cytotoxicity of anti-cancer drugs or other pharmaceutical compounds. The nonradioactive Roche Cell Proliferation Kit II (XTT) utilizes a spectrophotometer for quantification of cell proliferation and viability based on cleavage of the tetrazolium salt XTT in the presence of an electron-coupling reagent. Only viable cells can produce the soluble formazan salt, primarily related to glycolytic $\mathrm{NAD}(\mathrm{P}) \mathrm{H}$ production. Therefore, the amount of formazan dye formed directly correlated to the number of metabolically active cells in the culture.

Cells were seeded in a 96-well tissue culture plate at a density of 5,000 cells/well. At each time point, cells were incubated with the XTT labeling mixture for approximately 10-12 hours. After this incubation period, the formazan dye formed was quantitated using a Spectramax Plus ELISA reader, (Molecular Devices). The optimal wavelength used in our experiments was 500 $\lambda$. Values were generated using the software package, SoftMax Pro 4.8. Following manufacturer's instructions, cell viability was calculated separately for NI-07 and Taxol ${ }^{\mathrm{TM}}$ as follows: [Treated (NI-07 or Taxol ${ }^{\mathrm{TM}}$ ) - blank / control (Untreated) $\times 100 \%$. Cellular Cytotoxicity was calculated following the manufacturer's instructions as follows: ([Absorbance value of control (Untreated cells) - (Treated (NI-07 or Taxol ${ }^{\mathrm{TM}}$ ) - blank (XTT in medium only)] / control) $\times$ $100 \%$. Viability and Cytotoxicity during Recovery was calculated the same way. However, because untreated cells were not used during Recovery, the initial values generated during LC50 for the untreated (control) cells were repeated in the Recovery phase calculations. 


\subsection{Microscopy}

Images were generated using an Olympus I $\times 70$ inverted microscope under phase contrast conditions with a Lambda 10-2 shutter controller (Sutter Instruments Inc.) and a Hamamatsu Orca - ER highspeed camera. Objectives used were Olympus UPlan/FL 4X (yielding low magnification 40X images) and an Olympus LCPlan/FL 20x Ph1 objective (yielding higher magnification 200X images). Software used for image acquisition was SimplePCI v. 6. Images were captured at 300 DPI or greater using RGB color, 8 bits/channel settings.

\subsection{Statistical analysis}

To determine the effects of NI-07 on the cancer cells, an initial Two-way ANOVA was performed. If the results were significant at $\leq 0.05$, One-way ANOVA (including Tukey's HSD) was performed. The $p$ value for significance was set at $\leq 0.05$ for the ANOVA. In addition, Cohen's $d$ test for effect size was also performed to measure the strength of the relationship between the means for NI-07-treated and Untreated cells during LC50 and NI-07 and Taxol ${ }^{\mathrm{TM}}$ - treated cells during recovery. Even with a significant $\mathrm{p}$ value result, the degree of difference of the effect might not be appreciated. Cohen's d allowed a relative statistical assessment of whether NI-07 dramatically diverged from Untreated, outperformed Taxol $^{\mathrm{TM}}$ during Recovery or simply performed comparably. For the purposes of this study, based on the nature of the samples, Cohen's d values over 2.0 were considered to have a significant size effect relative to the cell numbers tested. Negative values indicated that the direction of the effect size favored NI-07. Positive values indicated that the direction of the effect size favored untreated or Taxol ${ }^{\mathrm{TM}}$.

\subsection{In vivo analysis}

To determine the effects of NI-07 in vivo, the human melanoma cell line WM-266-4 ${ }^{[21]}$ was selected for assessment in a $\mathrm{BALB} / \mathrm{c}$ nude mouse model. Melanoma is the least common, but most aggressive skin cancer, causing over $75 \%$ of skin cancer-related deaths ${ }^{[25]}$. Additionally, it is highly metastatic ${ }^{[25]}$. Therefore, the question of whether NI-07 could significantly reduce primary or secondary melanoma size and/or growth in the mouse model was addressed.

One hundred thousand melanoma cells were suspended in phosphate buffered saline (PBS) and mixed with Matrigel (BD Biosciences) in a weight ratio of 1:1 to obtain the mixture solution containing WM-266-4 cells. Fourteen 5-week-old female nude mice (BALB/c nu/nu) were each inoculated with $80 \mu \mathrm{l}$ of cell-matrigel mixture in the right flank. Mice were monitored until the mean value of tumor burden became 1000 based on the formula: Tumor burden $=\pi / 6 \times 0.5 \times$ length $\times$ (width)2. Five mice served as the positive treatment control group. Cisplatin was used as the positive treatment control due to its common use as a cocktail component in treating melanoma ${ }^{[27]}$. Cisplatin concentration was $0.0025 \mathrm{mg} / \mathrm{g}$, determined by calculating the weight of compound / body weight of mouse. The cisplatin was prepared by diluting a $10 \mathrm{mg} / 20 \mathrm{ml}$ stock with PBS. Mice were administered the cisplatin once daily throughout the experimental period, in a volume equating to $1 \%$ of their total body weight in order to deliver $0.05 \mathrm{mg} / \mathrm{mouse}$ via intraperitoneal injection (IP). Four mice were treated as the NI-07 test group. NI-07 was administered at $0.0035 \mathrm{mg} / \mathrm{g}$ (weight of compound / body weight of mouse) twice a day during treatment by gavage. PBS was administered as the negative control by gavage to 5 mice, following the same treatment parameters as NI-07 administration. Mice were anesthetized using isofluorane for treatment administration (twice daily, $12 \mathrm{~h}$ schedule) and to measure tumor size and body weight every 2 days. Mice were observed daily for signs of morbidity. Based on overall tumor burden of the untreated group, upon termination of the experimental time period, mice were euthanized, the tumors resected, weighed and measured, and the body weight of the mice was recorded. All in vivo experiments and animal handling conformed to the Republic of Korea national guidelines concerning Humane Care and Use of Laboratory Animals.

\section{Results and discussion}

Previously, we described the physical and chemical characteristics of the natural product compound NeoImmune ${ }^{\circledR}-07$ (NI-07) ${ }^{[23]}$. This $100 \%$ water-soluble compound is a mixture of several molecules implicated as having potential 
anticancer effects along with the novel reactive NI species. These compounds included 2-methyl-butyric acid, alanine, chlorogenic acid, sinigrin, and valine in addition to the active NI ingredient, which was confirmed to be $191.2 \mathrm{~g} / \mathrm{mol}$, existing in a dihydrate form, $\mathrm{C}_{8} \mathrm{H}_{13} \mathrm{NO}_{2} \cdot 2 \mathrm{H}_{2} \mathrm{O}{ }^{[23]}$. The focus of that study was to determine the effectiveness of NI-07 on breast cancer cells and the potential cytotoxic effects to normal cells. Results showed that NI-07 effectively killed 5 out of 5 breast cancer cell lines tested, while showing no cytotoxic effects on normal epithelial cells or normal fibroblast cells. In this study we sought to determine how effective NI- 07 was in its anticancer activity over a broad range of cancer types. To that end, in vitro studies were performed in 6 cancer cell lines derived from carcinomas, a sarcoma and a glioma. Furthermore, the effectiveness of NI-07 was tested in vivo against a melanoma xenograft model. For all cancers discussed, statistical data is for 2010 estimates.

\section{In vitro results}

Carcinomas are solid tumors derived from an ectodermal or endodermal origin ${ }^{[26]}$. Carcinomas are the most numerous cancer type making up approximately $85 \%$ of all cancers ${ }^{[26]}$. In this study, the non-small cell lung carcinoma cell line H1299 was used. Estimates for lung cancer diagnoses were 222,520, with over 157,300 cases terminal. Lung cancer is a considered a disease of aging, associated with smoking. The median age at death for lung cancer is 72 years of age ${ }^{[25]}$, with increasing mortality corresponding to each decade after age 35 . The overall 5 -year relative survival was only $15.8 \%$. Lifestyle is a major component of risk of occurrence. Current standards of treatment for lung cancer involve combinations of two or more agents. Examples of treatment combinations include Taxol ${ }^{\mathrm{TM}}$ and carboplatin, cisplatin and vinorelbine tartare, etoposide and cisplatin ${ }^{[28]}$. Each chemotherapy targets a specific cellular mechanism (for review introduction section) and all have devastating side effects to the patient ${ }^{[28]}$. Thus, there is still a critical need to find new drugs that will effectively treat the cancer without harming the normal cells and tissues.

Figure 1 represents the results from treatment with NI-07. Growth curves for LC50 and Recovery are shown in Figures 1A, 1B respectively. Results in Figure 1A indicate that the effects of NI-07 are attenuated until $48 \mathrm{~h}$ in comparison to Taxol ${ }^{\mathrm{TM}}$ and cell death in comparison to untreated increases dramatically. Figure 1C summarizes the One-way ANOVA results at each time point. During LC50, the level of significance between untreated and NI-07-treated is greatest at $4 \mathrm{~d}$ and $7 \mathrm{~d}$. These levels are also reflected in the massive effect size determined for those time points. The potential resistance of the cells to NI-07 was analyzed in week 2 (Figure 1B). Results show that while Taxol ${ }^{\mathrm{TM}}$ appeared to be more effective at killing the H1299 cells, by 7 d, there were no significant differences in cell death. The resulting effect size is also unremarkable. However, unlike TaxolTM, NI-07 is nontoxic to normal cells ${ }^{[15]}$. Therefore, therapy strategies could be adjusted in terms of concentrations and /or treatment regimes. Figure 1D consists of representative photomicrographs that demonstrate the dissimilar death morphologies between NI-07 and TaxolTM. NI-07 appears to impact the cytoplasmic constituents and morphology more than the nuclear material, in direct contrast to Taxol ${ }^{\mathrm{TM}}$ (arrows).

Adenocarcinomas are epithelial cancer originating in glandular tissue. Epithelial tissue is derived embryologically from any of the three primary germ layers ${ }^{[26]}$. These tumor types are characterized by having secretory properties. Adenocarcinomas not only cause the classic problems associated with malignancy, they also can introduce the confounding effect of wreaking physiologic havoc by disrupting the homeostatic endocrine balance. For this study, three different adenocarcinoma cell lines were used: AsPc-1 derived from ascites fluid from a pancreatic metastasis, PC-3 derived from a prostate cancer bone metastasis and TT derived from a medullary tumor of the thyroid.

Pancreatic cancer is difficult to treat due to the fact that these cancers are generally detected at advanced stages of malignancy. In 2010, an estimated 43,140 men and women were diagnosed with pancreatic cancer and $\geq 94 \%$ will die of the disease before the 5-year relative survival rate is reached. Currently, the drugs most commonly used for pancreatic cancer are 5-fluorouracil, capectabine and gemcitabine. Treatment with these drugs leads to debilitating side effects ${ }^{[25]}$ coupled with the loss of pancreatic function, which regulates key enzymes and hormones, and the potential for metastasis make the prognosis poor ${ }^{[25]}$. The lifetime risk for developing pancreatic cancer is 1 in 71 with a median age at onset of 73 years of age. After age 45, mortality rates increase significantly each decade from $8.3 \%$ for patients ages $45-54$, up to 
$30.9 \%$ for ages 75 and 84 . With the aging population of Baby Boomers, the incidence and mortality will likely increase due to the lack of convenient and accurate detection techniques unless anticancer agents can be found that effectively treat pancreatic cancer in advanced stages.

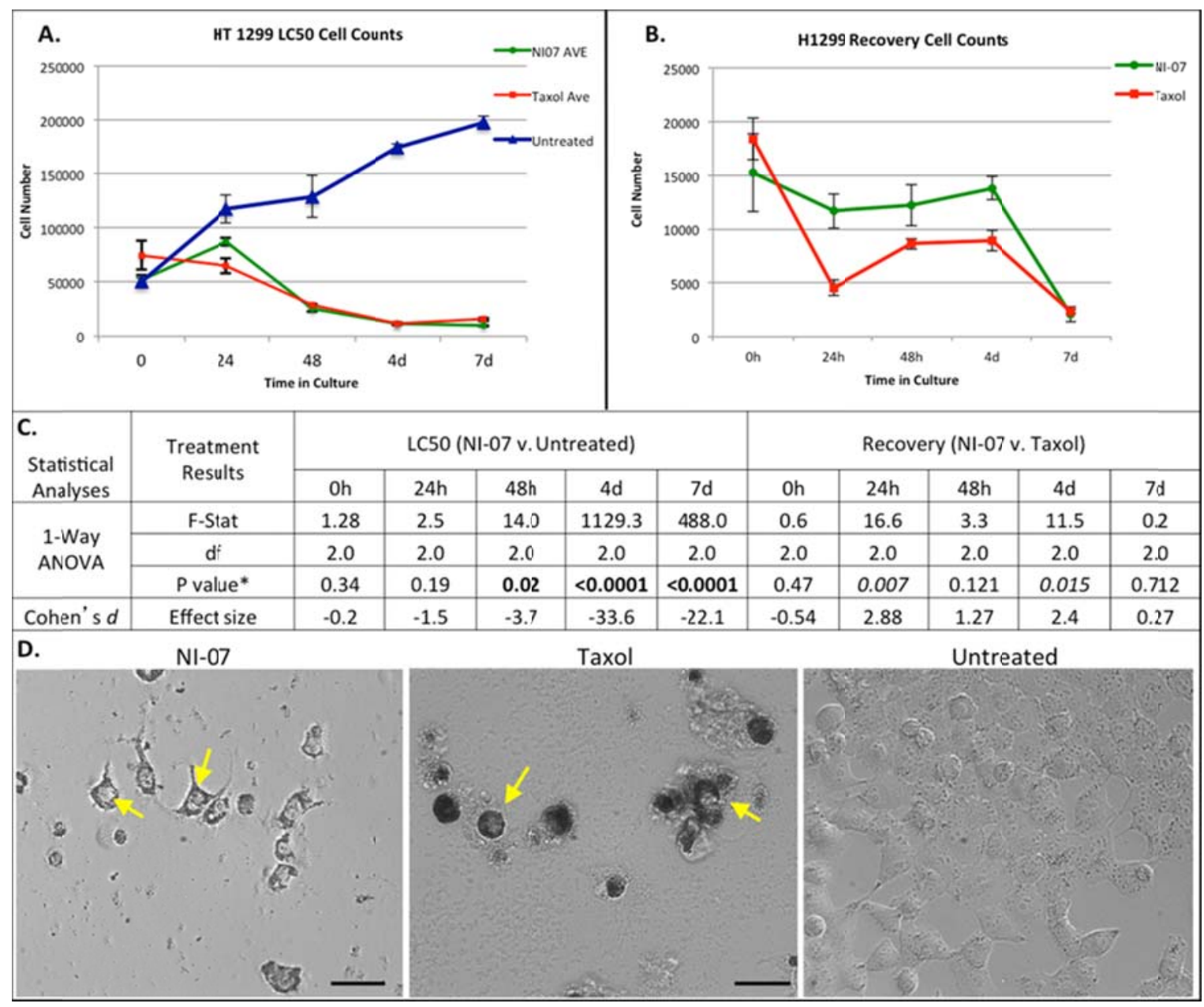

Figure 1. Results of H1299 Cell Response to NI-07 Treatment. A. LC50 cell growth curves. B. Recovery cell growth curves. Bars are standard error for the sample set at that time point. C. Summary statistics comparing NI-07-treated cells to Untreated cells in LC50 and NI-07-treated cells to Taxol ${ }^{\mathrm{TM}}$-treated cells in Recovery. Statistical tests: One-way ANOVA, Tukey's HSD and Cohen's d. $p \leq 0.05$. Bold responses indicate significance between NI-07 and Untreated. Italicized responses indicate significance between NI-07 treatment and Taxol ${ }^{\mathrm{TM}}$ treatment. D. Microscope images of H1299 cells at $7 \mathrm{~d}$ in NI-07, Taxol and Untreated conditions. Magnification $=200 \mathrm{X}$. Bar scale $=50 \mu \mathrm{m}$

Figure 2 demonstrates the effectiveness of NI-07 in vitro versus Untreated and Taxol ${ }^{\mathrm{TM}}$-treated AsPc-1cells. Figure $2 \mathrm{~A}$ shows the cell death trends for week 1 . As observed, there is a significant difference between NI-07 and Untreated cells after 24 h. Overall, NI-07 was more effective than Taxol ${ }^{\mathrm{TM}}$. Additionally, the effect size, measured by Cohen's $d$, indicates a dramatic difference between the interactions of the NI-07 and untreated AsPc-1 cell samples. During Recovery (Figure 2B) NI-07 demonstrated consistent cell death counts, indicating drug resistance was reduced in comparison to Taxol ${ }^{\mathrm{TM}}$. Figure $2 \mathrm{C}$ summarizes the statistical results. The level of significance between NI-07 versus untreated is striking. Additionally, the difference between NI-07 and Taxol ${ }^{\mathrm{TM}}$ during Recovery was also significant at the $p \leq 0.05$ level. The differences in morphology between the NI-07 and Taxol ${ }^{\mathrm{TM}}$-treated cells is demonstrated in Figure 2D. These photomicrographs taken under phase contrast conditions at $7 \mathrm{~d}$ clearly show the different effects each agent has on the AsPc-1 cells. Ni-07 cells are smaller, rounder and demonstrate cytoplasmic changes (arrows) resembling membrane 
thickening. In contrast, the Taxol ${ }^{\mathrm{TM}}$-treated cells are flatter, exhibiting membrane blebbing and disrupted nuclei (arrows). Untreated cells do not exhibit signs of stress, displaying a smooth cytoplasm in a connected monolayer. The images show that NI-07 exhibit a very different mechanism of action from TaxolTM, which disrupts cell cycle and motility via the microtubules. The differences are notable especially in the pancreatic cancer cells. The AsPC-1 cells treated with Taxol ${ }^{\mathrm{TM}}$ demonstrate the flattening, membrane blebbing and vacuole formation characteristic of Taxol ${ }^{\mathrm{TM}}$ induced apoptosis ${ }^{[24]}$. In contrast, the NI-07 treated AsPc-1 cells become very rounded, lift off the plate and then demonstrate what appears to be cytoplasmic "leakage".

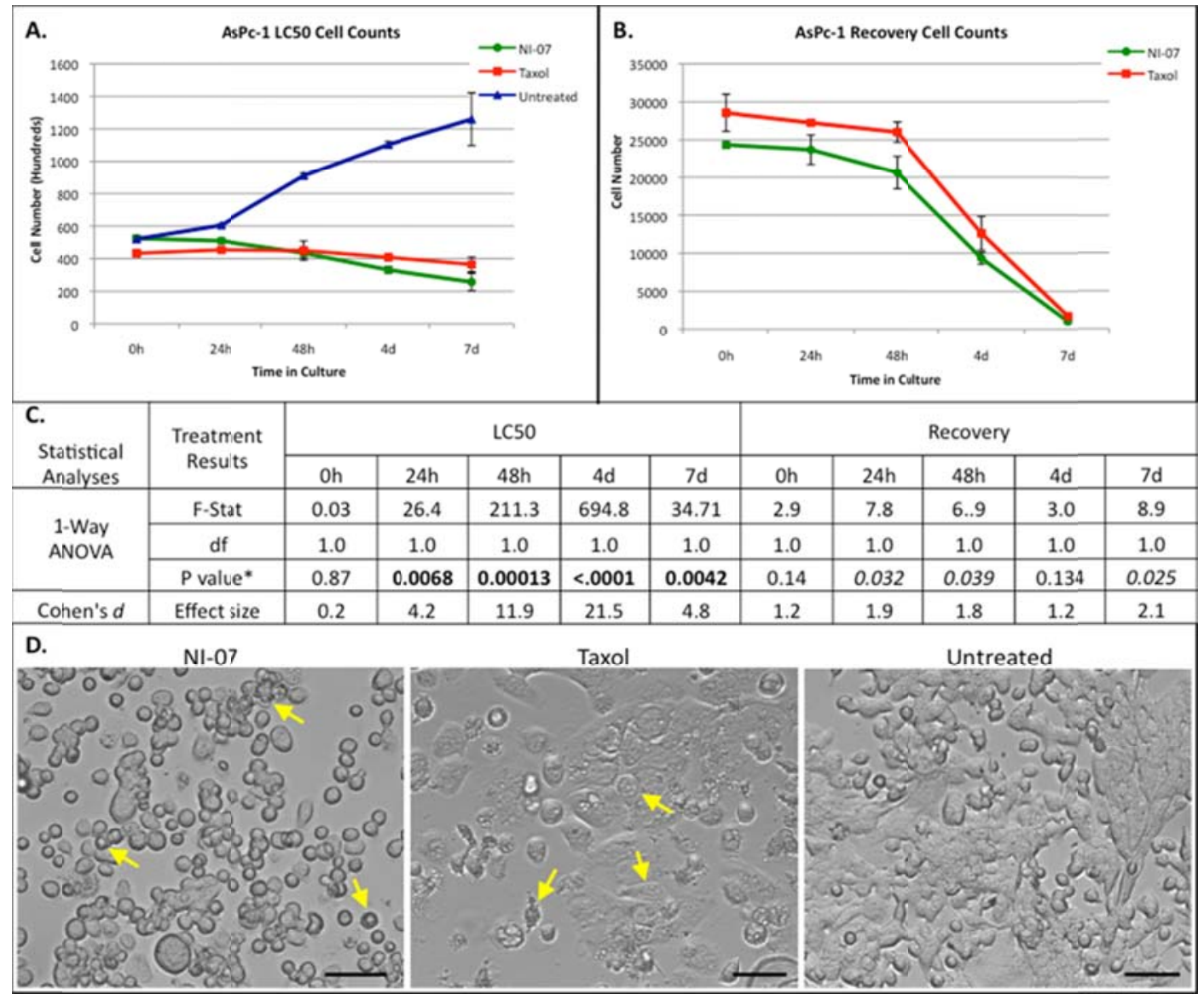

Figure 2. Results of AsPc-1 Cell Response to NI-07 Treatment. A. LC50 cell growth curves. B. Recovery cell growth curves. Bars are standard error for the sample set at that time point. C. Summary statistics comparing NI-07-treated cells to Untreated cells in LC50 and NI-07-treated cells to Taxol ${ }^{\mathrm{TM}}$-treated cells in Recovery. Statistical tests: One-way ANOVA, Tukey's HSD and Cohen's $d$. $p \leq 0.05$. Bold responses indicate significance between NI-07 and Untreated. Italicized responses indicate significance between NI-07 treatment and Taxol ${ }^{\mathrm{TM}}$ treatment. D. Microscope images of AsPc- 1 cells at $7 \mathrm{~d}$ in NI-07, Taxol and Untreated conditions. Magnification $=200 \mathrm{X}$. Bar scale $=50 \mu \mathrm{m}$

Incidence rates for prostate cancer are high with 1 in 6 men likely to be diagnosed with prostate cancer during their lifetime. In 2010, the estimated number of men to be diagnosed with prostate cancer was 217,730 with $\sim 32,000$ dying from the disease. Although mortality rates are low ${ }^{[25]}$, the incidence of occurrence is very high. Additionally, current diagnostic results can be ambiguous. Treatment consists of androgen deprivation therapy (ADT) or androgen suppression therapy, using luteinizing hormone-releasing hormone (LHRH) analogs, LHRH antagonists, anti-androgens, and other androgen-suppressing drugs such as ketoconazole. The goal is suppression of testosterone production ${ }^{[28]}$. Side effects to these treatments are difficult to alleviate and can be severe. Therefore it is critical that more effective anticancer agents be discovered for treatment of this disease. 
Figure 3 demonstrates the results of NI-07 treatment on PC-3 cells. As observed in Figure 3A, NI-07 affected PC-3 cell growth within $24 \mathrm{~h}$. Additionally, for the first $48 \mathrm{~h}$, NI-07 and Taxol ${ }^{\mathrm{TM}}$ results were very similar. However, while both were significantly effective in killing pancreatic cancer cells compared to untreated during LC50, after $4 \mathrm{~d}$ the effects of these anti-cancer agents began to diverge. This was especially evident in Recovery (Figure 3B) where PC-3 cell growth was significantly greater overall in Taxol ${ }^{\mathrm{TM}}$-treated cells. Both ANOVA and Cohen's d results showed that overall, NI-07 was not only effective in killing PC-3 cells, but was also more effective than Taxol ${ }^{\mathrm{TM}}$ treatment (Figure 3C). Figure D demonstrates the morphological disparities between untreated cells, NI-07 and Taxol ${ }^{\text {TM}}$-treated cells. As with previously described cell lines, there is a notable darkening and compaction of the cytoplasm in NI-07 treated cells. TaxolTM-treated cells exhibit hallmark traits of microtubule polymerization and spindle fiber disruption (arrows) leading to formation of multiple mini-nuclei.

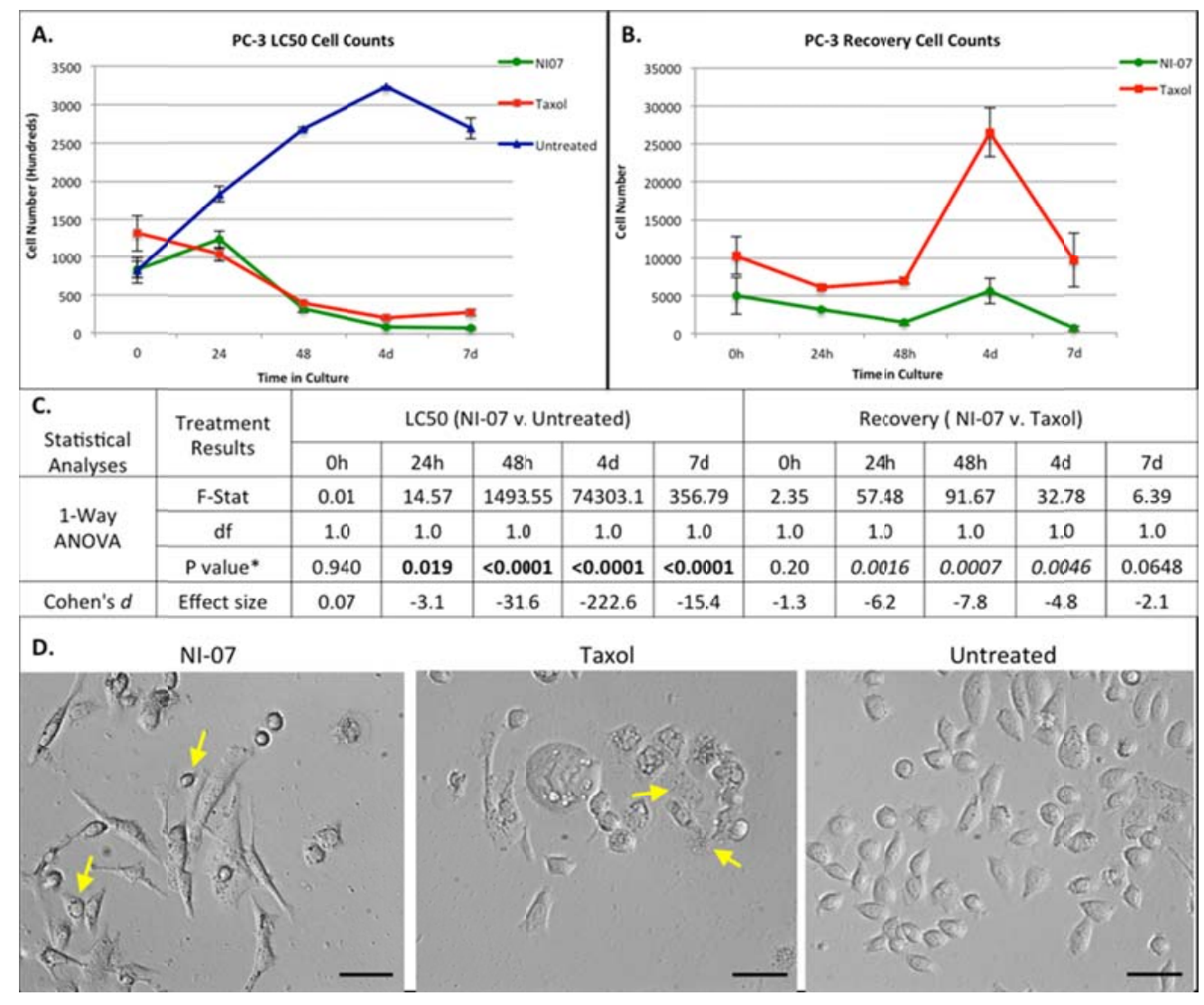

Figure 3. Results of PC-3 Cell Response to NI-07 Treatment. A. LC50 cell growth curves. B. Recovery cell growth curves. Bars are standard error for the sample set at that time point. C. Summary statistics comparing NI-07-treated cells to Untreated cells in LC50 and NI-07-treated cells to TaxolTM-treated cells in Recovery. Statistical tests: One-way ANOVA, Tukey's HSD and Cohen's d. $p \leq 0.05$. Bold responses indicate significance between NI-07 and Untreated. Italicized responses indicate significance between NI-07 treatment and Taxol ${ }^{\mathrm{TM}}$ treatment. D. Microscope images of PC-3 cells at $7 \mathrm{~d}$ in NI-07, Taxol and Untreated conditions. Magnification $=200 \mathrm{X}$. Bar scale $=50 \mu \mathrm{m}$

The final adenocarcinoma-derived cell line tested was the thyroid cancer line, TT. Unlike the previously discussed cancer, thyroid cancer occurs at a relatively young age. The median age at diagnosis for thyroid cancer is 49 years. Percent patients diagnosed are relatively consistent from age 20 to 74, peaking between 45 - 54 years of age. The overall 5-year relative survival was $97.3 \%$. The probability of developing thyroid cancer during a lifetime is 1 in 111 , with a gender bias of 1:3 against women. Additionally, although not generally fatal and usually local, it can lead to problems with hypothyroidism and hyperthyroidism - causing a multitude of other problems. Thus, usual clinical management protocols are hotly debated as to the extent of the resection because it is based on the degree of surgery that is optimal for T2 stage tumors $(1-4 \mathrm{~cm})$ 
with no metastases ${ }^{[29]}$. The major point of contention is that staging systems use patient age alone. As a result, young patients with high risk of occurrence but low mortality rates are lumped in the low risk by TNM or Age, Metastases, Extent, Size (AMES) classifications, used to justify unilateral lobectomy for the majority of patients ${ }^{[30]}$. Therefore, having a compound that can treat the cancer while salvaging the normal tissue would address this problem and improve the quality of life for the patient.

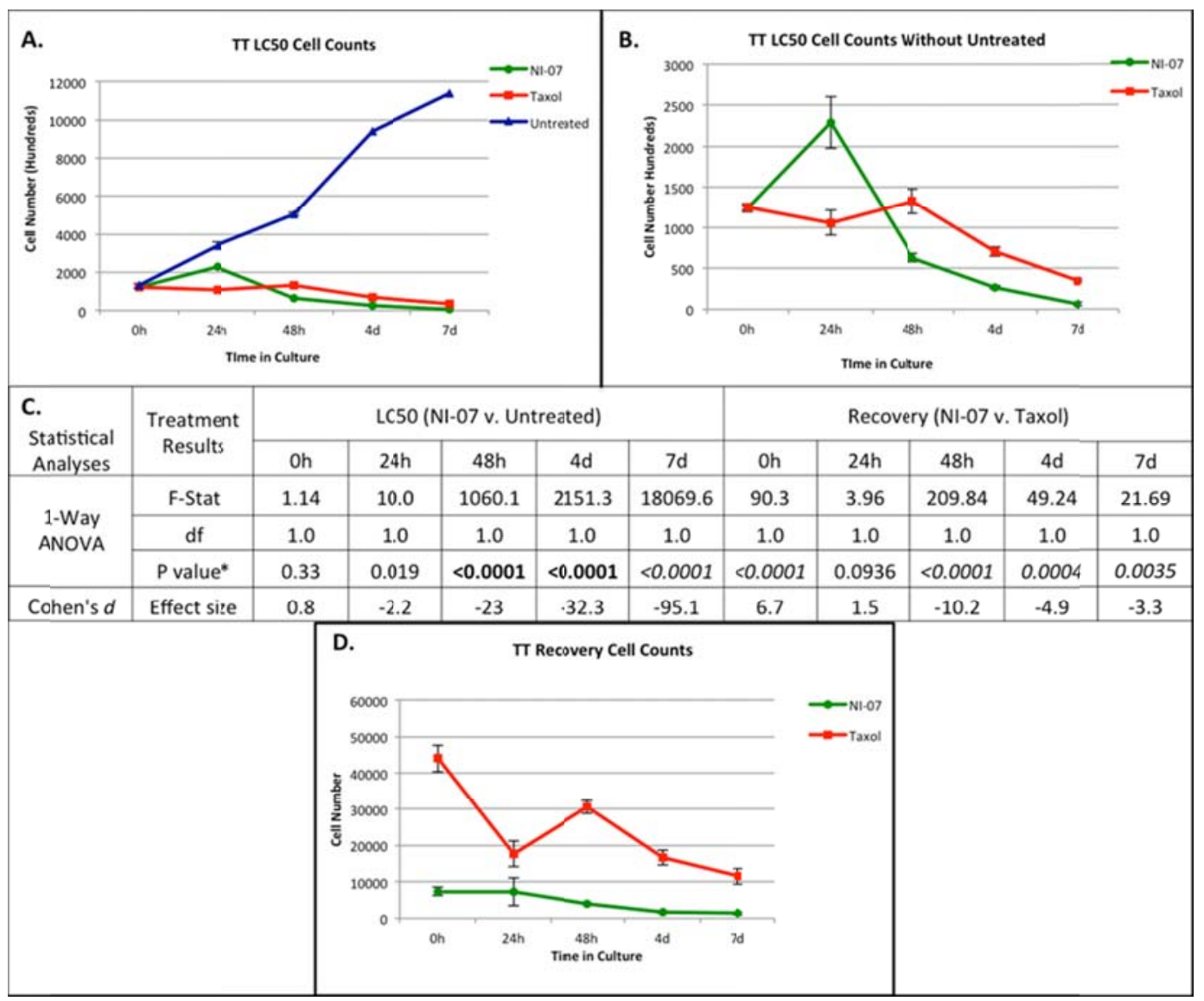

Figure 4. Results of TT Cell Response to NI-07 Treatment. A. LC50 cell growth curves including Untreated. B. LC50 cell growth curves excluding Untreated. Bars are standard error for the sample set at that time point. C. Summary statistics comparing NI-07-treated cells to Untreated cells in LC50 and NI-07-treated cells to Taxol ${ }^{\mathrm{TM}}$-treated cells in Recovery. Statistical tests: One-way ANOVA, Tukey's HSD and Cohen's $d . p \leq 0.05$. Bold responses indicate significance between NI-07 and Untreated. Italicized responses indicate significance between NI-07 treatment and Taxol $^{\mathrm{TM}}$ treatment. D. Recovery cell growth curves.

Figure 4 shows representative results from treatment with NI-07. TT cells are very small and compact (data not shown). Therefore untreated cultures grew to very high numbers. Figure 4A shows the results of treatment, including the untreated controls. Figure 4B shows the same results, excluding untreated. The difference in cell number on $7 \mathrm{~d}$ cannot be appreciated in Figure 4A. Figure 4B shows that the difference is almost 200 fold. ANOVA and Cohen's d summary statistics demonstrated that over the experimental sampling period, the level of significance for NI-07 effectiveness was consistently greater in both LC50 $(<0.0001)$ and Recovery $(7 \mathrm{~d}$ value $=0.0035)$. Figure $4 \mathrm{D}$ graphically shows that TT cells were significantly less resistant to NI-07 than Taxol ${ }^{\mathrm{TM}}$.

The next cell line tested, Saos-2, was derived from an osteosarcoma. A sarcoma is a tumor originating from the connective tissue cells, which arise from the mesodermal germ layer ${ }^{[26]}$. These solid tumors are fast growing, rare and primarily develop from connective tissue cartilage, bone and muscle. Sarcomas make up about $2 \%$ of total cancers ${ }^{[26]}$. 
It is estimated that $\sim 2600$ people will be diagnosed with osteosarcoma and about 1,500 people will die from the disease $^{[25]}$. Osteosarcoma in particular, is a cancer primarily occurring in young adults (16-18 years). It is a highly aggressive neoplasm typically composed of spindle cells producing osteoids. The outcome for patients with osteosarcoma is poor before the use of effective chemotherapy, with 2-year overall survival rates of $15 \%-20 \%$ following surgical resection and/or radiotherapy ${ }^{[25]}$. Combined chemotherapies (doxorubicin, cisplatin, high-dose methotrexate) have produced the most favorable outcomes ${ }^{[31]}$. However, there is a clear need for newer effective agents for patients with osteosarcoma, especially for patients who present with metastatic disease or develop disease recurrence. Marina et al ${ }^{[31]}$ eloquently summed up the current state of treatment with the sentence "It appears that we have reached the limit in the survival of osteosarcoma patients achievable with currently available chemotherapy".

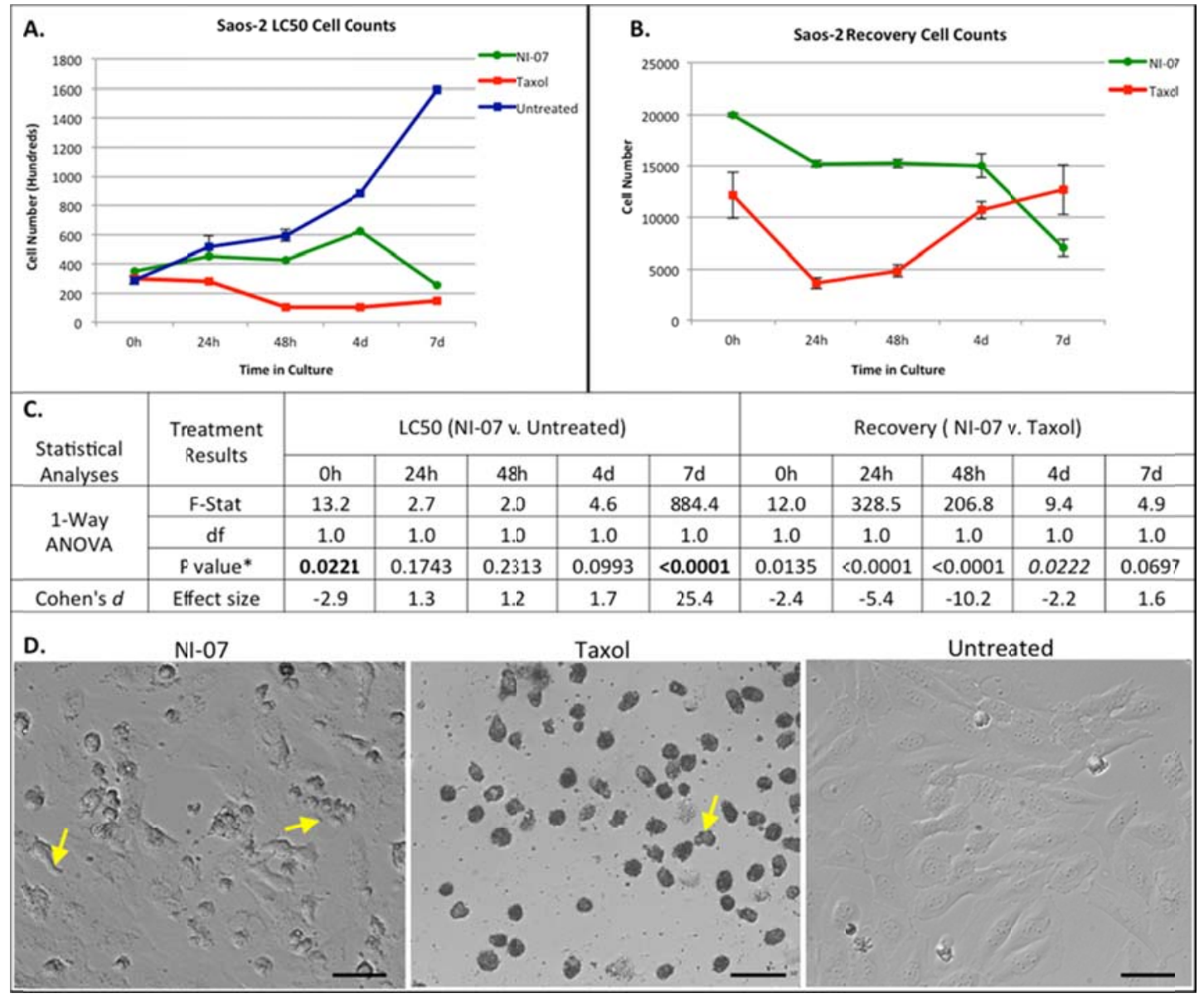

Figure 5. Results of Saos-2 Cell Response to NI-07 Treatment. A. LC50 cell growth curves. B. Recovery cell growth curves. Bars are standard error for the sample set at that time point. C. Summary statistics comparing NI-07-treated cells to Untreated cells in LC50 and NI-07-treated cells to Taxol ${ }^{\mathrm{TM}}$-treated cells in Recovery. Statistical tests: One-way ANOVA, Tukey's HSD and Cohen's d. $p \leq 0.05$. Bold responses indicate significance between NI-07 and Untreated. Italicized responses indicate significance between NI-07 treatment and Taxol ${ }^{\mathrm{TM}}$ treatment. D. Microscope images of Saos- 2 cells at $7 \mathrm{~d}$ in NI-07, Taxol and Untreated conditions. Magnification $=200 \mathrm{X}$. Bar scale $=50 \mu \mathrm{m}$.

Figure 5 demonstrates the results from the treatment of Saos-2 with NI-07. From the results in Figure 5A, it is evident that Saos-2 was the most resistant to NI-07 treatments. Figure 5C reveals that the anticancer effects were not significant from untreated until $7 \mathrm{~d}$. However, the Recovery curves are more promising. Figure 5B shows a downward trend at $24 \mathrm{~h}$ Recovery that remains stable until $4 \mathrm{~d}$ at which time the remaining cells averaged $\sim 7000$ in culture. Additionally, the cytotoxicity, as measured by XTT, became more potent than Taxol ${ }^{\mathbf{T M}}$ by $7 \mathrm{~d}$ Recovery. This result was also mirrored by the sharp decline in cell viability at $7 \mathrm{~d}$ LC50 and again at $7 \mathrm{~d}$ Recovery (data not shown). Furthermore, it is important to Published by Sciedu Press 
note that although NI-07 treatment may not appear as effective as Taxol ${ }^{\mathrm{TM}}$ in LC50, cells in Taxol ${ }^{\mathrm{TM}}$ Recovery appeared to become resistant and increased in number from $24 \mathrm{~h}$ to $7 \mathrm{~d}$. At $7 \mathrm{~d}$, the number of Saos- 2 cells was greater than the initial number counted at $0 \mathrm{~h}$ Recovery in contrast to NI-07 treated cells, which were only $1 / 3$ of the cells initially counted at $0 \mathrm{~h}$ Recovery. Therefore, while slower to affect the cells, the effect of NI-07 was more consistent and did not allow recovery cell growth to occur.

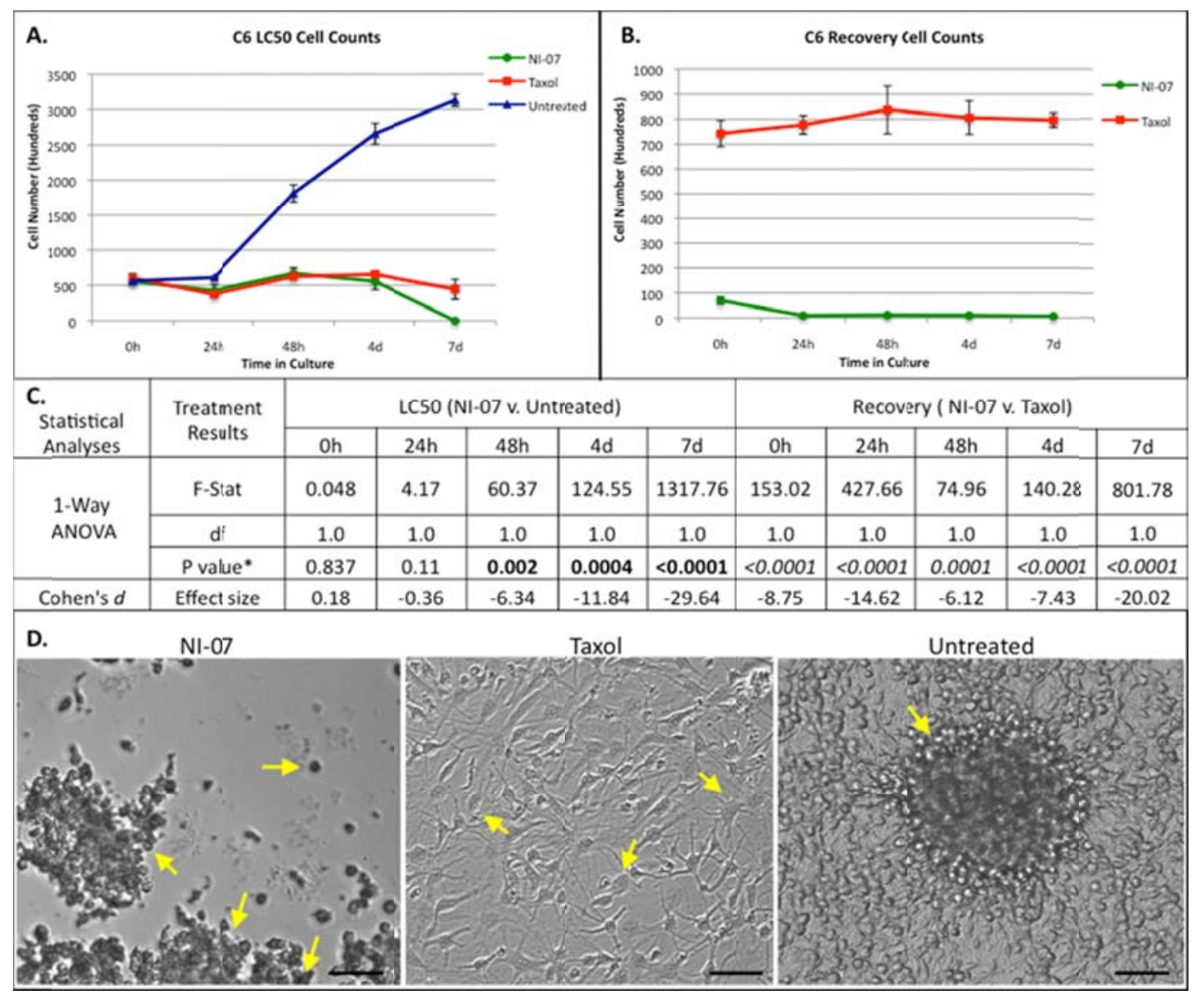

Figure 6. Results of C6 Cell Response to NI-07 Treatment. A. LC50 cell growth curves. B. Recovery cell growth curves. Bars are standard error for the sample set at that time point. C. Summary statistics comparing NI-07-treated cells to Untreated cells in LC50 and NI-07-treated cells to Taxol ${ }^{\mathrm{TM}}$-treated cells in Recovery. Statistical tests: One-way ANOVA, Tukey's HSD and Cohen's d. $p \leq 0.05$. Bold responses indicate significance between NI-07 and Untreated. Italicized responses indicate significance between NI-07 treatment and Taxol ${ }^{\mathrm{TM}}$ treatment. D. Microscope images of C6 cells at $7 \mathrm{~d}$ in NI-07, Taxol and Untreated conditions. Magnification $=200 X$. Bar scale $=50 \mu \mathrm{m}$.

Gliomas are tumors of the brain that originate from the glial cells. High-grade gliomas are very vascular and as a result, they exhibit high infiltration rates ${ }^{[26]}$. This tumor growth can cause the adjacent blood-brain-barrier to break down. Recurrence of high-grade gliomas is over $90 \%$, even after complete surgical excision. Thus, gliomas are rarely curable. The prognosis for patients with high-grade gliomas is generally poor. Of 10,000 Americans diagnosed each year with malignant gliomas, about half survive past the first year after diagnosis, and only $25 \%$ live past the second year. The median age at diagnosis is 56 years with an overall 5 -year relative survival of $\sim 35 \%$ for all brain cancers ${ }^{[25]}$. Those with Glioblastoma multiforme have a worse prognosis, surviving less than a 12-month average post-diagnosis. With newer treatment strategies, this has been increased to 14 months ${ }^{[32]}$. Current treatments for glioma are limited by accessibility to the tumor as well as difficulty in penetrating the blood-brain-barrier with current chemotherapeutic agents. Furthermore, there is strong consideration for the danger these agents could pose to neurons and neural junctions. Thus, it is essential that newer and better treatment be found that can cross the blood-brain-barrier without harming the normal neural tissues. 
The results of NI-07 treatment on C6 glioma cells is presented in Figure 6. These in vitro results are the most striking in delineating the effectiveness of NI-07 compared to both untreated and Taxol ${ }^{\mathrm{TM}}$-treated cells. In Figure 6A, a significant divergence from untreated cell growth is observed after $48 \mathrm{~h}$. By $7 \mathrm{~d}$ there are few cells left in culture. This trend is continued in Recovery (Figure 6B) in which NI-07 was significantly more effective at treating the glioma cells. No resistance was observed. The results of the ANOVA and effect size are summarized in Figure 6C. Notably, the level of significance is maintained throughout the Recovery period with NI-07 having $80-100 \mathrm{X}$ less cells than Taxol ${ }^{\mathrm{TM}}$. Figure 6D consists of representative photomicrographs at $7 \mathrm{~d}$ LC50 taken under phase contrast at 400X.

The cell morphology for both treatments is quite different from that observed in the untreated cells, which form foci when confluent. From these micrographs, the nonviable cells in the NI-07-treated wells are in stark contrast to the remaining TaxolTM-treated cells. NI-07 caused the cells become detached, compact, dark floating clusters of cells, whereas the glioma cells treated with Taxol ${ }^{\mathrm{TM}}$, although appearing stressed, maintained a resistant population of cells throughout the experiment. Water solubility and small molecule size may give NI-07 an advantage in penetrating the blood-brain-barrier. Importantly, its lack of cytotoxicity to normal cells would allow administration without fear of irreparable damage to the neural tissue.

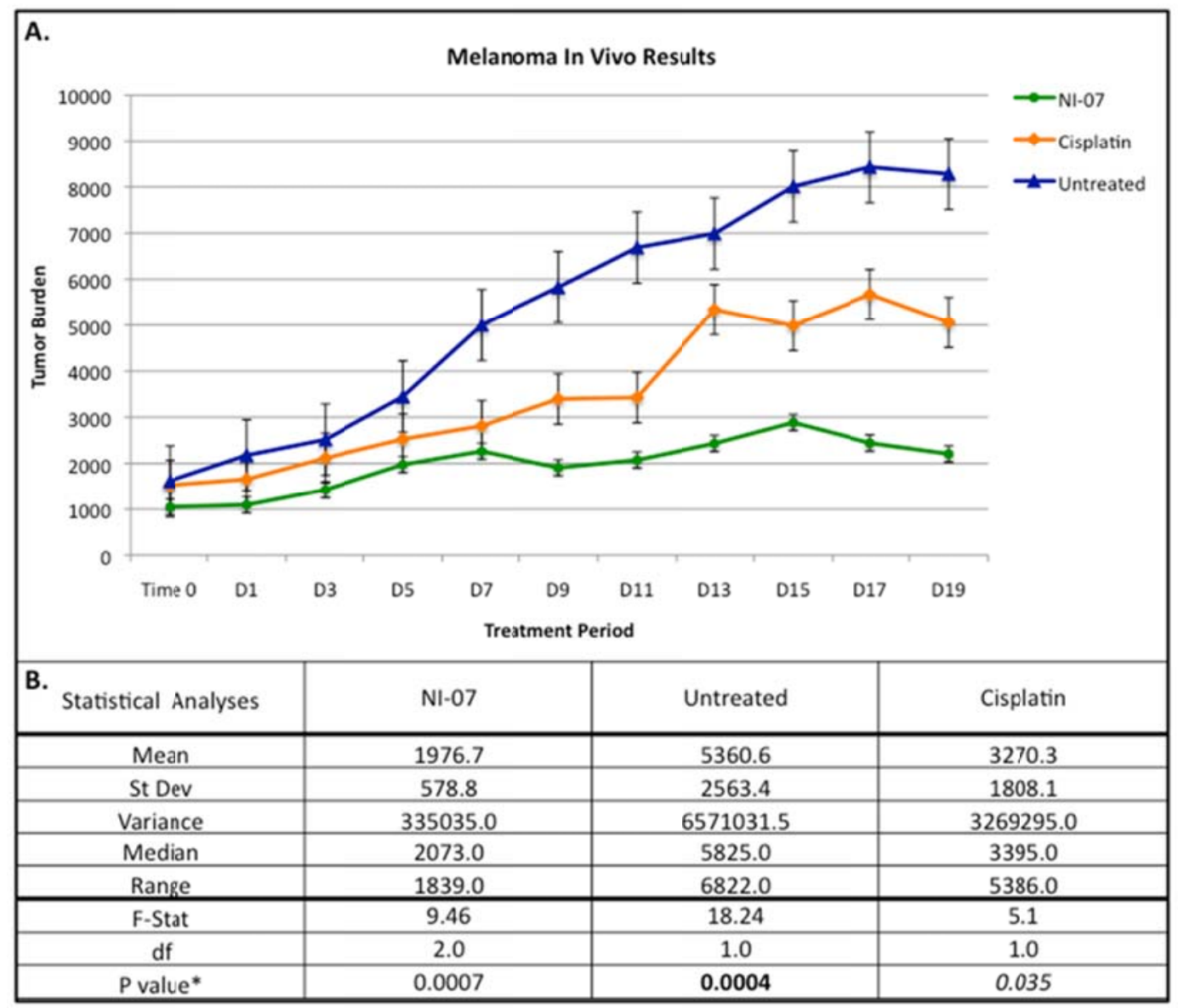

Figure 7. NI-07 Effectiveness In Vivo Against Melanoma. WM-266-4 cells were injected into the right flank of Balb/c mice. A. Graphic representation of experimental results. Untreated mice were the negative controls (PBS alone); Positive control consisted of 5 mice treated with cisplatin $(0.0025 \mathrm{mg} / \mathrm{g})$. Experimental group of 4 mice received NI- 07 $2 \mathrm{X}$ per day at $0.0035 \mathrm{mg} / \mathrm{g}$ body weight. $\mathrm{D}=$ day during treatment. $\mathrm{D}-1$ indicates initial time point for commencement of treatment. Y axis is the tumor burden as calculated by $\pi / 6 \times 0.5 \times$ length $\times($ width $) 2$. B. Statistical summary results of One-way ANOVA comparing NI-07 against Untreated and cisplatin. $p \leq 0.05$ 
Melanoma develops from disrupted melanocytes, the pigment producing cells of the epidermis. Although the least common of the skin cancers, melanoma is the most lethal, causing $\sim 75 \%$ of skin cancer-associated mortalities ${ }^{[25]}$. Lifetime risk of developing melanoma is 1 in 52. Due to the ubiquitous nature of melanocytes and the subdermal location adjacent to blood vessels, if not diagnosed early, melanoma more readily metastasizes than other solid tumors. The treatment includes surgical removal of the tumor, adjuvant therapy, Chemotherapy, immunotherapy, and/or radiation therapy. Early diagnosis plays a key role in prognosis of recovery and risk of recurrence. It is estimated that 68,130 men and women will be diagnosed with melanoma. The median age at diagnosis is 60 and the median age at death due to melanoma is 68 . The overall 5 -year relative survival for melanoma is estimated at $\sim 91 \%$. However, there is an ethnicity-based difference in survivorship. Five-year relative survival for Caucasians is $\sim 90 \%$, whereas African Americans drop to $\sim 75 \%$, primarily due to the difficulty in detecting the discolored lesion against the darker pigmentation ${ }^{[25]}$.

In order to determine whether NI-07 would be effective against melanoma, we employed a Cancer-Mouse Melanoma Model. The mouse model system is widely accepted as a fundamental in vivo, mammalian testing system for human disease ${ }^{[33]}$. By utilizing a live animal study, any confounding or synergistic effects or hormone signaling and metabolism may be observed. In addition, potential side effects as well as bio-activation and the ability of the body to clear the drug or its derivatives can also be measured.

The results from the in vivo study are presented in Figure 7. From the graph, it can be observed that NI-07 significantly slowed the tumor growth in comparison to untreated and cisplatin-treated mice. These significant differences from untreated were not observed until five days after treatments commenced. Significant differences from untreated in the cisplatin-treated mice were not observed until 9 days after initial treatment (almost twice as long). The One-way ANOVA for NI-07 compared to both untreated and cisplatin-treated mice showed significance to 0.007 . When NI-07 was compared to untreated mice, the divergence was more significant to 0.0004. NI-07 in comparison to cisplatin, one of the main drugs used against melanoma, was also significant at 0.035 . Empirical observations of mice daily activity levels indicated no evident side effects from NI-07 administration. Activity levels, feeding, social behaviors were highest in the NI-07-treated mice versus the other groups.

\section{Conclusions}

Within the scope of this study, in vitro analysis of the candidate anti-cancer agent NI-07 was performed in six different cancer cell lines representing the major solid tumor types as well as tumors derived from cells representing the three primary germ cell layers. Taxol ${ }^{\mathrm{TM}}$ was used as positive control and untreated cells served as the negative control group. Our results showed that NI-07 demonstrated significant anticancer properties against all the cell lines tested. Significant effects were observed after $24 \mathrm{~h}$ in AsPc-1, PC-3 and TT cells, 48 h in H1299 and C6 cells and 7d in Saos-2 cells. Interestingly, the fastest response was observed in the adenocarcinomas, while the most attenuated response was observed in the osteosarcoma cells. From our previous work ${ }^{[34]}$ and the work of others (for review see ${ }^{[35]}$ ), TaxolTM is known to induce apoptosis within the first $24 \mathrm{~h}$. In addition, the morphological changes that occur as a result of TaxolTM exposure were observed ${ }^{[36]}$, (i.e., microtubule polymerization, the formation of multiple micronuclei, plasma membrane blebbing, etc.). Morphological changes induced by NI-07 demonstrated features very disparate from Taxol ${ }^{\mathrm{TM}}$.

We are currently investigating the mechanism(s) by which NI-07 kills cancer cells. Furthermore, and potentially more importantly, we are attempting to dissect the process that prevents cancer cell recovery even after removal of NI-07. Based on as yet unpublished data generated in our lab, as well as other studies ${ }^{[37-39]}$, we hypothesize that paraptosis is the major mechanism of programmed cell death initiated by NI-07. Paraptosis is a caspase-independent programmed cell death, characterized by membrane bound organelle swelling, most notably the endoplasmic reticulum (ER) and the mitochondria ${ }^{[40-42]}$. This swelling and vacuolization has been shown to be involved with disruption of intracellular ion homeostasis resulting in a heat shock proteins response ${ }^{[43]}$, among other inducers ${ }^{[44]}$. This speculation is based on the 
morphological changes observed in this study and our prior study ${ }^{[15]}$ as well as our unpublished XTT assay results. Studies show that XTT dye reduction occurs at the cell surface facilitated by trans-plasma membrane electron transport of which, mitochondrial oxidoreductases are major contributors ${ }^{[45]}$. Experiments to confirm these results are currently being performed. The long lasting effects of NI-07 may be due to the inability of the cell to reinstate intracellular ion homeostasis. Our previous studies on calcium fluctuations in paclitaxel-induced ER-associated apoptosis ${ }^{[24,46,47]}$ and others ${ }^{[41,44,48,49]}$, make calcium a likely candidate for further investigation.

A definitive test of the effectiveness is application to an in vivo model of cancer. In this study, we investigated the effectiveness of NI-07 against a human melanoma xenograft mouse model. Although NI-07 did not cause total remission of the cancer, there was a significant reduction in tumor burden and growth over the test period $(p \leq 0.004)$. Our previous study demonstrated that NI-07 has no cytotoxic effects to normal cells ${ }^{[23]}$ and the mice treated with NI-07 were the most vigorous of the three treatments groups. Thus the possibility exists that NI-07 could be administered either at higher concentrations or for longer treatment periods or both with little side effects or reduction in the quality of life for the patient. Additionally, NI-07 may also be useful as an adjuvant therapy or used to preload the patient prior to administration of current chemotherapeutics, conferring a protective mechanism to the normal cells while targeting cancer cells destruction. Finally, our results indicate that NI-07 has potential to be developed as an effective anticancer agent for a very broad range of solid cancer types.

\section{Competing interests}

The authors declare they have no competing interests.

\section{Author's contributions}

LSG designed and carried out some of the cell count and XTT experiments, collated the data, performed the statistical analyses, directed VL and KL for remaining in vitro experiments and wrote the manuscript. VL and KL contributed to cell count and XTT experiments. YJ isolated and purified NI-07 and supervised the in vivo studies.

\section{Acknowledgements and funding}

We wish to acknowledge the TTU Biotechnology Core Facilities for access to the Thermolyne Speed Vacuum Centrifuge and Plate Reader. This study was supported through a grant from Yusahng LLC to LSG (TTU) and YJ (SNU). Funds were also provided by the TTU Office of the Vice President for Research and the Department of Biological Sciences.

\section{References}

[1] Splinter TA. Paclitaxel and carboplatin as neoadjuvant chemotherapy in operable (stage I and II) and locally advanced (stage IIIA-N2) non-small cell lung cancer. Semin Oncol. 1996; 23(6 Suppl 16):59-61. PMid:9007124

[2] Pajk B, Cufer T, Cervek J, Zakotnik B. First-line chemotherapy with cisplatin, methotrexate and vinblastine in metastatic bladder cancer. Tumori. 1996; 82(5): 453-455. PMid:9063522

[3] Barker CA, Chang M, Lassman AB, Beal K, Chan TA, Hunter K, Grisdale K, et al. Medical and Neuro-Oncology. Neuro-Oncology. 2010; 12(suppl 4): iv36-iv57. http://dx.doi.org/10.1093/neuonc/noq116.s6

[4] Goldberg JM, Piver MS, Hempling RE, Recio FO. Paclitaxel and cisplatin combination chemotherapy in recurrent epithelial ovarian cancer. Gynecol Oncol. 1996; 63(3):312-317. PMid:8946864 http://dx.doi.org/10.1006/gyno.1996.0328

[5] Donat SM, Herr HW, Bajorin DF, Fair WR, Sogani PC, Russo P, Sheinfeld J, Scher I. Methotrexate, vinblastine, doxorubicin and cisplatin chemotherapy and cystectomy for unresectable bladder cancer. J Urol. 1996, 156(2 Pt 1): 368-371. PMid:8683681

[6] Sobell HM. Actinomycin and DNA transcription. Proc Natl Acad Sci U S A. 1985; 82(16): 5328-5331. PMid:2410919 http://dx.doi.org/10.1073/pnas.82.16.5328

[7] Koch U, Krause M, Baumann M. Cancer stem cells at the crossroads of current cancer therapy failures--radiation oncology perspective. Semin Cancer Biol. 2010; 20(2):116-124. PMid:20219680 http://dx.doi.org/10.1016/j.semcancer.2010.02.003

[8] Chen H, Khemtong C, Yang X, Chang X, Gao J. Nanonization strategies for poorly water-soluble drugs. Drug Discov Today. 
[9] Gelderblom H, Verweij J, Nooter K, Sparreboom A. Cremophor EL: the drawbacks and advantages of vehicle selection for drug formulation. Eur J Cancer. 2001; 37(13):1590-1598. http://dx.doi.org/10.1016/S0959-8049(01)00171-X

[10] Chua TC, Yan TD, Saxena A, Morris DL. Should the Treatment of Peritoneal Carcinomatosis by Cytoreductive Surgery and Hyperthermic Intraperitoneal Chemotherapy Still be Regarded as a Highly Morbid Procedure?: A Systematic Review of Morbidity and Mortality. Annals of Surgery. 2009; 249(6):900-907. PMid:19474692 http://dx.doi.org/10.1097/SLA.0b013e3181a45d86

[11] Mohamed F, Moran BJ. Morbidity and Mortality With Cytoreductive Surgery and Intraperitoneal Chemotherapy: The Importance of a Learning Curve. The Cancer Journal. 2009; 15(3): 196-199. PMid:19556904 http://dx.doi.org/10.1097/PPO.0b013e3181a58d56

[12] Counter CM, Gupta J, Harley CB, Leber B, Bacchetti S. Telomerase activity in normal leukocytes and in hematologic malignancies. Blood. 1995; 85: 2315-2320. PMid:7727765

[13] Sliwkowski MX, Lofgren JA, Lewis GD, Hotaling TE, Fendly BM, Fox JA. Nonclinical studies addressing the mechanism of action of trastuzumab (Herceptin). Semin Oncol. 1999; 26(4 Suppl 12): 60-70. PMid:10482195

[14] Roukos DH. Innovative genomic-based model for personalized treatment of gastric cancer: integrating current standards and new technologies. Expert Rev Mol Diagn. 2008; 8(1): 29-39. PMid:18088228 http://dx.doi.org/10.1586/14737159.8.1.29

[15] Gollahon L, Jeong Y, Finckbone V, Lee K, Park J-S. The Natural Product NI-07, Is Effective Against Breast Cancer Cells While Showing No Cytotoxicity to Normal Cells. The Open Breast Cancer Journal. 2011; 3: 31-44. http://dx.doi.org/10.2174/1876817201103010031

[16] Chen WH, Horoszewicz JS, Leong SS, Shimano T, Penetrante R, Sanders WH, Berjian R, Douglass HO, Martin EW, Chu TM. Human pancreatic adenocarcinoma: in vitro and in vivo morphology of a new tumor line established from ascites. In vitro. 1982; 18(1): 24-34. PMid:7182348 http://dx.doi.org/10.1007/BF02796382

[17] Giaccone G, Battey J, Gazdar AF, Oie H, Draoui M, Moody TW. Neuromedin B is present in lung cancer cell lines. Cancer Res 1992; 52(9 Suppl): 2732s-2736s. PMid:1563005

[18] Kaighn ME, Narayan KS, Ohnuki Y, Lechner JF, Jones LW. Establishment and characterization of a human prostatic carcinoma cell line (PC-3). Invest Urol. 1979; 17(1): 16-23. PMid:447482

[19] Berger CL, de Bustros A, Roos BA, Leong SS, Mendelsohn G, Gesell MS, Baylin SB. Human medullary thyroid carcinoma in culture provides a model relating growth dynamics, endocrine cell differentiation, and tumor progression. J Clin Endocrinol Metab 1984; 59(2): 338-343. PMid:6736207 http://dx.doi.org/10.1210/jcem-59-2-338

[20] Rodan SB, Imai Y, Thiede MA, Wesolowski G, Thompson D, Bar-Shavit Z, Shull S, Mann K, Rodan GA. Characterization of a Human Osteosarcoma Cell Line (Saos-2) with Osteoblastic Properties. Cancer Research. 1987; 47(18): 4961-4966. PMid:3040234

[21] Westermark B, Johnsson A, Paulsson Y, Betsholtz C, Heldin CH, Herlyn M, Rodeck U, Koprowski H. Human melanoma cell lines of primary and metastatic origin express the genes encoding the chains of platelet-derived growth factor (PDGF) and produce a PDGF-like growth factor. Proceedings of the National Academy of Sciences of the United States of America. 1986; 83(19): 7197-7200. PMid:3020539 http://dx.doi.org/10.1073/pnas.83.19.7197

[22] Benda P, Lightbody J, Sato G, Levine L, Sweet W. Differentiated rat glial cell strain in tissue culture. Science. 1968; 161(839): 370-371. PMid:4873531 http://dx.doi.org/10.1126/science.161.3839.370

[23] Gollahon L, Jeong Y, Finckbone V, Lee K, Park J. The Natural Product NI-07, Is Effective Against Breast Cancer Cells While Showing No Cytotoxicity to Normal Cells. The Open Breast Cancer Journal. 2011; 3: 31-44. http://dx.doi.org/10.2174/1876817201103010031

[24] Pan Z, Gollahon L. Taxol directly induces endoplasmic reticulum-associated calcium changes that promote apoptosis in breast cancer cells. Breast J. 2010; 17(1): 56-70. PMid:21073601 http://dx.doi.org/10.1111/j.1524-4741.2010.00988.x

[25] Jemal A, Siegal R, Xu J, Ward E. Cancer statistics, 2010. CA: a cancer journal for clinicians. 2010; 60(5): $277-300$. PMid:20610543 http://dx.doi.org/10.3322/caac.20073

[26] Papadopoulos NE, Bedikian A, Ring S, Kim KB, Hwu WJ, Gerber DL, Homsi J, Hwu P. Phase I/II Study of a Cisplatin-Taxol-Dacarbazine Regimen in Metastatic Melanoma. Am J Clin Oncol. 2009; 32(5): 509-514. PMid:19506454 http://dx.doi.org/10.1097/COC.0b013e3181942a1f

[27] Ruddon R: Cancer Biology. 4th edition. Oxford, UK: Oxford University Press; 2007: 568.

[28] Reni M, Balzano G, Aprile G, Cereda S, Passoni P, Zerbi A, Tronconi MC, et al. Adjuvant PEFG (cisplatin, epirubicin, 5-fluorouracil, gemcitabine) or gemcitabine followed by chemoradiation in pancreatic cancer: a randomized phase II trial. Ann Surg Oncol. 2012; 19(7): 2256-2263. PMid:22237835 http://dx.doi.org/10.1245/s10434-011-2205-2

[29] Droge P. Protein tracking-induced supercoiling of DNA: a tool to regulate DNA transactions in vivo?[Review]. Bioessays. 1994, 16(2): 91-99. PMid:8147849 http://dx.doi.org/10.1002/bies.950160205 
[30] McGriff NJ, Csako G, Gourgiotis L, Guthrie LC, Pucino F, Sarlis NJ. Effects of thyroid hormone suppression therapy on adverse clinical outcomes in thyroid cancer. Annals of Medicine. 2002; 34(7): 554-564. PMid:12553495 http://dx.doi.org/10.1080/078538902321117760

[31] Mazzaferri EL, Kloos RT. Clinical review 128: Current approaches to primary therapy for papillary and follicular thyroid cancer. J Clin Endocrinol Metab. 2001; 86(4): 1447-1463. http://dx.doi.org/10.1210/jc.86.4.1447

[32] Marina N, Gebhardt M, Teot L, Gorlick R. Biology and therapeutic advances for pediatric osteosarcoma. Oncologist. 2004; 9(4): 422-441. PMid:15266096 http://dx.doi.org/10.1634/theoncologist.9-4-422

[33] de Lange T. Human Telomeres are Attached to the Nuclear Matrix. EMBO J EMBO Journal. 1992; 11:717-724.

[34] Olive KP, Tuveson DA. The Use of Targeted Mouse Models for Preclinical Testing of Novel Cancer Therapeutics. Clinical Cancer Research. 2006; 12(18):5277-5287. PMid:17000660 http://dx.doi.org/10.1158/1078-0432.CCR-06-0436

[35] Pan Z, Gollahon L. Taxol Directly Induces Endoplasmic Reticulum-Associated Calcium Changes That Promote Apoptosis in Breast Cancer Cells. The breast journal. 2011; 17(1): 56-70. PMid:21073601 http://dx.doi.org/10.1111/j.1524-4741.2010.00988.x

[36] McGrogan BT, Gilmartin B, Carney DN, McCann A. Taxanes, microtubules and chemoresistant breast cancer. Biochim Biophys Acta. 2008; 1785(2): 96-132. PMid:18068131

[37] Chen L, Zheng S, Willingham MC. [Mechanism of taxol-induced apoptosis in human breast cancer cells]. Zhonghua Zhong Liu Za Zhi. 1997; 19(2):103-106. PMid:10743071

[38] Hoa N, Myers MP, Douglass TG, Zhang JG, Delgado C, Driggers L, Callahan LL, VanDeusen G, Pham JT, Bhakta N et al: Molecular mechanisms of paraptosis induction: implications for a non-genetically modified tumor vaccine. PloS one. 2009; 4(2): e4631. PMid:19247476 http://dx.doi.org/10.1371/journal.pone.0004631

[39] Li B, Zhao J, Wang CZ, Searle J, He TC, Yuan CS, Du W. Ginsenoside Rh2 induces apoptosis and paraptosis-like cell death in colorectal cancer cells through activation of p53. Cancer letters. 2011; 301(2):185-192. PMid:21194832 http://dx.doi.org/10.1016/j.canlet.2010.11.015

[40] Wang Y, Li X, Wang L, Ding P, Zhang Y, Han W, Ma D. An alternative form of paraptosis-like cell death, triggered by TAJ/TROY and enhanced by PDCD5 overexpression. Journal of cell science. 2004; 117(Pt 8): 1525-1532. PMid:15020679 http://dx.doi.org/10.1242/jcs.00994

[41] Sperandio S, de Belle I, Bredesen DE. An alternative, nonapoptotic form of programmed cell death. Proc Natl Acad Sci U S A. 2000; 97(26): 14376-14381. PMid:11121041 http://dx.doi.org/10.1073/pnas.97.26.14376

[42] Sperandio S, Poksay K, de Belle I, Lafuente MJ, Liu B, Nasir J, Bredesen DE. Paraptosis: mediation by MAP kinases and inhibition by AIP-1/Alix. Cell death and differentiation. 2004; 11(10):1066-1075. PMid:15195070 http://dx.doi.org/10.1038/sj.cdd.4401465

[43] Wyllie AH, Golstein P. More than one way to go. Proc Natl Acad Sci U S A. 2001; 98(1):11-13. PMid:11136242 http://dx.doi.org/10.1073/pnas.98.1.11

[44] Melcher A, Todryk S, Hardwick N, Ford M, Jacobson M, Vile RG. Tumor immunogenicity is determined by the mechanism of cell death via induction of heat shock protein expression. Nature medicine. 1998; 4(5): 581-587. PMid:9585232 http://dx.doi.org/10.1038/nm0598-581

[45] Jambrina E, Alonso R, Alcalde M, del Carmen Rodriguez M, Serrano A, Martinez AC, Garcia-Sancho J, Izquierdo M. Calcium influx through receptor-operated channel induces mitochondria-triggered paraptotic cell death. The Journal of biological chemistry. 2003; 278(16): 14134-14145. PMid:12571238 http://dx.doi.org/10.1074/jbc.M211388200

[46] Berridge MV, Herst PM, Tan A. Tetrazolium dyes as tools in cell biology: New insights into their cellular reduction. Biotechnology Annual Review. 2005; 11: 127-152. http://dx.doi.org/10.1016/S1387-2656(05)11004-7

[47] Pan Z, Gollahon L. Paclitaxel attenuates Bcl-2 resistance to apoptosis in breast cancer cells through an endoplasmic reticulum-mediated calcium release in a dosage dependent manner. Biochemical and biophysical research communications. 2013, 432(3): 431-437. PMid:23415863 http://dx.doi.org/10.1016/j.bbrc.2013.01.130

[48] Pan Z, Gollahon L. Paclitaxel induces apoptosis in breast cancer cells through different calcium - regulating mechanisms depending on external calcium conditions. 2013.

[49] Yoon MJ, Kim EH, Kwon TK, Park SA, Choi KS. Simultaneous mitochondrial Ca(2+) overload and proteasomal inhibition are responsible for the induction of paraptosis in malignant breast cancer cells. Cancer letters. 2012; 324(2): 197-209. PMid:22634500 http://dx.doi.org/10.1016/j.canlet.2012.05.018

[50] Yoon MJ, Kim EH, Lim JH, Kwon TK, Choi KS. Superoxide anion and proteasomal dysfunction contribute to curcumin-induced paraptosis of malignant breast cancer cells. Free radical biology \& medicine. 2010; 48(5): 713-726. PMid:20036734 http://dx.doi.org/10.1016/j.freeradbiomed.2009.12.016 